Article

\title{
Forgetting History: Mediated Reflections on Occupy Wall Street
}

\author{
Michael S. Daubs ${ }^{1}$ and Jeffrey Wimmer ${ }^{2, *}$ \\ ${ }^{1}$ School of English, Film, Theatre and Media Studies, Victoria University of Wellington, 6011 Wellington, New Zealand; \\ E-Mail: michael.daubs@vuw.ac.nz \\ 2 Department of Media, Knowledge and Communication, University of Augsburg, 86135 Augsburg, Germany; \\ E-Mail: jeffrey.wimmer@phil.uni-augsburg.de \\ * Corresponding author
}

Submitted: 1 April 2017 | Accepted: 26 July 2017 | Published: 22 September 2017

\begin{abstract}
This study examines how Occupy Wall Street (OWS) protestors' practices and stated understanding of media act on social perceptions of networked media. It stems from a discursive content analysis of online commentary from OWS protestors and supporters, using different sources from the first Adbusters blog in July 2011 until May 2012. We demonstrate how the belief in the myth of an egalitarian Internet was incorporated into the offline structure of OWS and led OWS participants to adopt rhetoric that distances the movement from past protest actions by stating the movement was "like the Internet".
\end{abstract}

\section{Keywords}

discursive content analysis; media logic; mediatisation; Occupy Wall Street; protest movement

\section{Issue}

This article is part of the issue "Acting on Media: Influencing, Shaping and (Re)Configuring the Fabric of Everyday Life", edited by Sigrid Kannengießer and Sebastian Kubitschko (University of Bremen, Germany).

(C) 2017 by the authors; licensee Cogitatio (Lisbon, Portugal). This article is licensed under a Creative Commons Attribution 4.0 International License (CC BY).

\section{Introduction}

This past September marked the fifth anniversary of the Occupy Wall Street (OWS) movement. Since that time, several facets of the movement-including its success, failures, and even its very nature-have been subject to debate in both the popular and academic press. One common thread in these debates, however, has been the movement's important relationship with various forms of media. This paper attempts to reconsider the role media play in the development of recent protest movements in ways that go beyond misguided terms such as "Twitter"-, "Facebook"- and/or "Tumblr-Revolutions" or more useful examinations of the use of media to mobilise, organise, or "choreograph" - to borrow Paolo Gerbaudo's (2012, p. 4) term-protest actions.

In the introduction to their edited volume Mediation and Protest Movements, Bart Cammaerts, Alice Mattoni and Patrick McCurdy $(2013$, p. 11) argue that media are important to social movements because "without (self-) mediation, insurrectionary performances and acts of resistance become meaningless". They assert that social movements should organise staged events that lead to visibility in a mass mediated public sphere (Cammaerts et al., 2013, p. 11). Protest actions even in the so-called "Internet age", such as the anti-WTO [World Trade Organization] demonstrations in Seattle, followed this media logic. Dubbed the "Battle in Seattle", these protests attracted between forty and fifty thousand protesters in Seattle, inspired simultaneous protest actions in cities around the globe, and garnered a significant amount of media attention from news organizations in multiple countries. Technologies such as the Internet and mobile communication-particularly text messaging - certainly played a role in the organisation of these protests (see, for example, Eagleton-Pierce, 2001; Mudhai, 2006; Rheingold, 2002; Smith, 2006).

As we outline in detail below, the concept of mediatisation provides a different framework for understanding OWS, particularly because it helps examine "processes through which the possession and use of certain media are constructed as central" (Hepp, 2009, pp. 43-44). 
While staging events in order to win the attention of mass media was occasionally mentioned in early communications about OWS, the role that digital, networked media played in OWS and other "New Social Movements" or NSMs (see Lievrouw, 2011)-which combine an emphasis upon collective, long-term actions supported by social media-eventually became a primary focus. James Compton and Nick Dyer-Witheford (2014, p. 1203) argue that, while "the preconditions for Occupy Wall Street (OWS) lay in material conditions...the spark was virtual", while Manuel Castells (2012, p. 229) simply claims that Occupy is specifically a unique product of an Internet age by saying it was "born digital". In doing so, Castells exhibits a "technological-fascination bias", i.e., "the tendency of treating the latest technological platform as a fetish when considering social movements" (Mattoni \& Treré, 2014, p. 255).

In this paper, we problematise the notion that OWS was 'born digital' while acknowledging the central role that digital, networked media played in the selfmediation of OWS. Following Alice Mattoni and Emiliano Treré (2014, p. 258), who suggest that a "focus on social practices might be a useful starting point to further discuss how media intertwine with social movements", we argue that the early OWS movement both incorporated long-standing protest practices while simultaneously adopting self-mediating rhetoric distancing OWS from past protest actions, positioning the movement as representative of a new era of social movements. Our primary research question is: How did those who participated in the early OWS movement (either in person or online) understand and historically contextualise the movement in public (self-) representations, both in terms of connections to sociocultural and economic developments and to previous social movements?

While Mattoni and Treré (2014, p. 253) suggest that their framework, "in contrast to short-term, instrumental, and enthusiastic accounts on the role of media within mobilizations, is able to support further empirical analysis on how past and present social movements interact with the media at large", we believe a focus on (offline) practices and organisation can also be useful in examining the full influence of media in developing social movements. In essence, we are considering the ways OWS protestors acted on media in two different ways. First, we are examining the ways in which those involved in OWS reflected upon media, their affordances, and their characteristics, and how these reflections both represented and fuelled social (mis)understandings of media, particularly the conceptualisation of digital, networked media as egalitarian and democratising. Second, we examine how the protestors used these conceptions of media to describe and contextualise OWS. We are thus modifying Mattoni's and Treré's approach of focusing on media practices "to see media at work in a number of contexts and situations, and-more importantly-to understand how media practices arrange, combine, and more generally intersect with other social practices" (Mattoni
\& Treré, 2014, p. 259) to instead examine what the protestors' own self-mediation and their social practices reveal about the relationship between the two.

\section{Research Objects and Methodology}

Our study stems from a discursive content analysis of online commentary from OWS protestors and supporters (in the popular press and user-generated media) during the first few months of the movement, from the first announcement on the Adbusters blog in July 2011 through May 2012, when some OWS protestors proclaimed that "Occupy Wall Street is now dead" (Adbusters, 2012c). The selected sources include online publications written and maintained by OWS participants including occupywallstreet.org (which is simply a domain name that redirects to the Adbusters blog), occupy.com, The Occupied Wall Street Journal at occupiedmedia.us, and groundswellcollective.com. These sources represent some of the most visible and popular sources of information for those participating in or curious about OWS at the time. In addition, we also surveyed the Occupy Gazette, a community newspaper produced by members of OWS that was available both online and in print and distributed throughout the encampment and the surrounding area.

Reflecting the varied backgrounds of the participants themselves, these texts were written by a wide variety of people including participants writing under pseudonyms (e.g., womyn), local and national professionals-turnedactivists including programmers (Gupta, Burch), writers and journalists (e.g., Sacks, Schneider, McNeil), artists (e.g., Knodel, Nocenti, Gueraseva), and academics (e.g., Graeber). Fifteen posts were written by an unnamed staff member at Adbusters, while two posts featured on the blog The Occupied Wall Street Journal were written by the relatively well-known activist writers Naomi Klein and Chris Hedges. Any quotation that specifically mentioned the structure or organisation of OWS, the horizontal, deliberative process used in the OWS encampments, or digital or social media was selected for inclusion.

Common themes identified in these comments were then used to search for and identify both supportive and critical editorials featured on a variety of sites such as CNN, Fox News, The Guardian, Salon, and even the pop culture website Bleeding Cool. These latter sources, as will be discussed below, demonstrate how the rhetoric used by OWS protestors was echoed in other discussions of the movement. In total, our sample is comprised of 163 quotations pulled from 65 different articles and posts found in fourteen online sources.

\section{Results}

\subsection{OWS Processes-An Overview}

The Occupy movement arose as a reaction to aggressive globalisation that was exacerbating a global finan- 
cial crisis, at the same time as the social use of digital tools was becoming naturalised. The simultaneity of these developments is perhaps what contributes to the framings of OWS as arising from digital media. The original economic focus of OWS, however, suggests the movement has its roots in protest movements extending back several decades if not centuries. The earliest social and protest movements focused on economic issues such as labour, capital and class divisions (della Porta \& Diani, 2006, pp. 6-9). As a result, Marxist approaches to studying social movements were dominant throughout the 1960s, particularly in Europe and the United States, when a wave of protests led to increased academic interest in social movement theory (della Porta \& Diani, 2006, p. 1; Jasper, 2010, p. 965). Both protestor and academic interest in these largescale, society-wide issues related to capitalism and classbased issues waned in comparison to "smaller-scale movements more focused on wide-ranging issues or concerns (e.g., green/environmentalism, animal rights, antinuclear, anti-globalization, consumer rights), or group identity or lifestyle (e.g., the women's movement, gay rights, national/ethnic/language cultural/religious identity movements" in the late 1960s through the 1980s (Lievrouw, 2011, pp. 41-42). However, as Donatella della Porta and Mario Diani (2006, p. 2) note:

At the start of the new millennium, possibly for the first time since 1968, the wave of mobilizations for a globalization from below (often identified as the global justice movement), seems to have the potential for a global, generalized challenge, combining themes typical of class movements with themes typical of new social movements, like ecology or gender equality.

A number of social movement scholars describe OWS as an outgrowth of the global justice or anti-globalisation movement that "came to world attention with the 1999 Seattle protests against the World Trade Organization" (Hayduk, 2012, p. 43). Sasha Costanza-Chock (2012, p. 376) notes that the first call to occupy Wall Street was "circulated by Adbusters magazine, a publication that gained visibility during the height of the Global Justice Movement as an important home for high production value ad-hacking, brand contamination and détournement" - thus situating OWS squarely within the genealogy of the anti-globalisation movement. Ron Hayduck (2012, p. 46) also explicitly links OWS to the anti-WTO protests in Seattle and the global justice movement that emerged around the start of the millennium, noting their similar economic precursors:

The economic change wrought by neoliberal globalization during the decades preceding Seattle and during the decade leading up to OWS - particularly the Great Recession-elevated and exposed key targets (WTO, banks) in new ways, and also galvanized progressive groups in the struggle for global justice.
Furthermore, he traces the origins of the global justice movement itself to previous protest actions in South Africa (the Anti-Apartheid movement) and Mexico (the Zapatista uprising). While he does not elaborate on why he sees the Anti-Apartheid movement as an important precursor, he again focusses on the role of globalisation and neoliberalism in positioning the Zapatistas as an antecedent to the global justice movement. Noting how the group formed on the day the North American Free Trade Agreement took effect, he argues the group "explicitly" challenged neoliberalism and "articulated a sharp critique of the impact these policies had on indigenous peoples in Mexico" (Hayduk, 2012, p. 45).

Hayduk (2012, p. 46) also notes that "OWS activists repeatedly make explicit connections to Tunisia, Egypt, Spain, Italy, Greece, and so on". Costanza-Chock (2012, p. 376) similarly argues that OWS was inspired by protests in Tunisia, the Middle East and North Africa as well as "Spanish 'Indignados' mobilizations and Greek anti-austerity uprisings". The protests in Spain and Greece in particular were direct inspirations for OWS. As della Porta (2012) and Castañeda (2012) note, the Indignados movement in Spain was a response to the global economic crisis, which was causing a severe economic downturn in that country, and the response of the European Union and the Spanish government to that crisis. On May 15, 2011, organisers asked people to "to take the square, 'Toma la Plaza', and called for an acampada" (Castañeda, 2012, p. 311). Protestors responded in strength, occupying hundreds of squares across the country.

Theses protests in Spain not only directly inspired similar protests in an equally economically-stressed Greece (della Porta, 2012, p. 274), but the economic conditions and the tactic of occupying public squares firmly establish the Indignados movement as a direct predecessor to OWS. As Amalia Cardenas (as cited in Castañeda, 2012, p. 318) succinctly summarises, "The Occupy Wall Street is the same movement as the Indignados".

Much like the Indignados occupations, the encampments in Zuccotti Park (later renamed to Liberty Square) in New York incorporated a complex, leaderless, and horizontal organisational model. Small working groups generated ideas for presentation to the general assembly and actions to be taken were then determined by consensus, determined using hand signals, in a method that resembles the debate, deliberation and consensus formation (or contestation) process in online spaces such as message boards, Facebook groups, Twitter, wikis, and blogs (see, for example, Dahlberg, 2001, 2007, 2011; Dahlgren, 2001; Fenton \& Downey, 2003). OWS even avoided designating official spokespeople to represent the group (Bennett \& Segerberg, 2016, p. 92). Furthermore, OWS exhibited a philosophy of integration through diversification, i.e., the acceptance of all perspectives, issues, and opinions discussed openly in the collective, longrunning protests (Daubs, 2017). The emphasis on fluid, open exchanges is exemplified by popular slogans such "We are the 99" which emphasise the diversity of opin- 
ion within the movement while simultaneously asserting its inclusiveness.

\subsection{The (Self-)Mediation of OWS}

This horizontalism would become a key characteristic of the movement, as comments from OWS participants below demonstrate. However, those participating in and writing about OWS in blog posts and op-eds that contributed to the public face of the movement seemingly prioritise the influence of digital media in conceptualisations of the movement. The sections below discuss three of the major themes identified in our content analysis, including ways protestors historically situated the movement, the emphasis they put on the deliberative processes of the movement, and how protestors described the movement in relation to media-especially digital, networked media such as the Internet.

\subsubsection{Historical Contextualisation of OWS}

The content analysis of the OWS materials reveals that those involved in the Occupy movement did see some loose historical connections between OWS and previous social movements. Commentators drew parallels between OWS and the American Revolution (Adbusters, 2011a), the Perestroika movement and Glasnost in Russia in the mid-to-late-1980s, (Gueraseva, 2012), the antiglobalisation protests in Seattle in 1999 (Klein, 2011), and Gandhi's protests in India in the early $20^{\text {th }}$ century, if only for OWS's "commitment to absolute nonviolence in the Gandhian tradition" (Adbusters, 2011g). By far, however, the most common historical mentions in these texts were of the American Civil Rights movement and the "May Uprising" and wildcat general strike of 1968 (Adbusters, 2011c, 2011f, 2011h, 2012b, 2012c, 2012e; Elliott, 2011; Graeber, 2011a; Gupta, 2011; Rushkoff, 2011). These connections are shallow at best. While David Graeber (2011a) notes that the deliberative process adopted by OWS "has deep roots in American radical history" and was "widely employed in the civil rights movement and by the Students for a Democratic Society", Arun Gupta (2011) simply notes that OWS represented "a unique opportunity to peacefully shift the tides of history like the sit-down strikes of the 1930s, the civil rights movement of the 1960s and the democratic uprisings across the Arab world and Europe today". In other words, Gupta is simply acknowledging that all social movements, including OWS, can be "levers of social change" (Castells, 2012, p. 218) rather than noting, as Graeber does, that the movement extends from and adopts practices of earlier movements.

In fact, of the 18 collected comments that referenced protests and social movements from before the turn of the century, there were almost as many dedicated to de- scribing how OWS different from those movements (Elliott, 2011; Klein, 2011) or simply hoping they would not fail like previous movements (Adbusters, 2012b, 2012e) as there were those that acknowledge the role played by historical antecedents (Adbusters, 2011f; Graeber, 2011a, 2011b; Gueraseva, 2012; Schneider, 2011a). Adbusters (2012b) simply asked, for example, “May 1968 was the first wildcat general strike in history...it lasted two weeks and was a grand gesture of refusal still remembered, but then it fizzled...maybe this May we won't?". Adbusters co-founder and editor in chief Kalle Lasn argued in an interview with Salon.com that "1968 was more of a cultural kind of revolution. This time I think it's much more serious" (Elliott, 2011). Finally, one April 2012 Adbusters post made the division between OWS and previous movements explicit, stating the movement was facing "a fight to the finish between the impotent old left and the new vibrant, horizontal left who launched Occupy Wall Street from the bottom-up" (Adbusters, 2012b).

\subsubsection{A Focus on Process over Past}

In short, despite gestures to history, it appears historical antecedents played only a minor role in OWS protestors' conceptualisation of the movement. Instead, the collected comments suggest participants were originally far more interested (at first) in process, in-person actions, deliberation, and horizontalism and these ways these were inspired by other, contemporary movements such as the Arab Spring and the Spanish Indignados movement rather than earlier movements. A post in early October 2011 to the Occupied Wall Street Journal explains that the General Assembly, the central decisionmaking body of OWS in which anyone could participate, was "a horizontal, autonomous, leaderless, modifiedconsensus-based system with roots in anarchist thought, and it's akin to the assemblies that have been driving recent social movements around the world in places like Argentina, Egypt's Tahrir Square, Madrid's Puerta del Sol and so on" (Schneider, 2011b).

A large number of posts (22) from a variety of sources (9) emphasised the importance of this leaderless, consensus-based direct democracy, some including descriptors such as "wonderful" (Klein, 2011), "rewarding" (Burtch, 2011; Chelliah, 2012), and "the purest form of democracy" (Schneider, 2011a). ${ }^{1}$ When the New York City General Assembly (NYCGA, 2011), the leaderless group of OWS protestors that debated issues and made decisions via consensus, posted their "Principles of Solidarity", for example, they noted: "Through a direct democratic process, we have come together as individuals and crafted these principles of solidarity, which are points of unity"; furthermore, they labelled these principles a "living document" that could be further amended, but only

\footnotetext{
${ }^{1}$ See Adbusters (2011a, 2011b, 2011d, 2011i, 2012a, 2012b, 2012d), Bleeding Cool (2011), Burtch (2011), Chelliah (2012), Elliott (2011), Graeber (2011a), Harris (2011), Hedges (2011), Klein (2011), Noveck (2011), Occupy the SEC Working Group (2012), Rushkoff (2011), Schneider (2011a, 2011b), and womyn (2011).
} 
"through the democratic process". Another OWS participant posting under the name "grim womyn" (2011) stated that "many are feeling the hope that real change can emerge from this leaderless movement in which people are leaving their homes to occupy their communities". Furthermore, while the original Adbusters (2011e) post called for protesters to "incessantly repeat one simple demand in a plurality of voices", the "occupation itselfand the direct democracy taking place there" (Schneider, 2011b) became the goal of OWS.

While some, such as Graeber (2011a), did acknowledge a horizontal structure had been used before by other groups, there was a sense that the scale and scope of this model OWS was attempting was something new. As Graber (2011a) himself notes:

It was, in the least, a wild gamble, because as far as any of us knew, no one had ever managed to pull off something like this before. Consensus process had been successfully used in spokes-councils-groups of activists organized into separate affinity groups, each represented by a single "spoke" - but never in mass assemblies like the one anticipated in New York City. Even the General Assemblies in Greece and Spain had not attempted it.

Similarly, artist Ann Nocenti claimed "Many people have trouble understanding the Occupy movement, because it is something quite new" (Bleeding Cool, 2011).

\subsubsection{A Mediated/Mediatized Understanding of OWS}

Scholars such as Costanza-Chock (2012, p. 381) point out, however, that many of the so-called innovations of the Occupy movement actually have a long history that pre-dates the Internet by decades if not centuries. Hayduk (2012, p. 47), for example, notes that "OWS has drawn from several methods popularized in the AntiGlobalization movement, such as the general assembly and 'spokes-council' models, which were pioneered in Porto Alegre, Argentina, Chiapas, and Seattle". In addition, many of the practices and philosophies demonstrated by the Occupy protestors are not dependent upon digital media. As Sean Scalmer (2013, pp. 118-119) notes, "Gandhian" types of non-violent protests were "successfully dispersed through the use of print technology, the telegraph, relatively slow forms of international transport, and steady, organizational labour". Gerbaudo (2012, p. 134) asserts that horizontal political and social structures are not the providence of digital media alone; rather, social movements often depend upon "soft leadership", a fact which can be masked by analyses that privilege digital and social media. Similarly, Mattoni and Treré (2014, p. 257) observe that social movements "usually lack formal hierarchies, adopt decision-making processes based on participation, and value the first-person commitment of activists, often because they frequently lack material resources such as money". In short, a non- violent, horizontal organisation based upon participation and deliberation is not particular to protest movements in a digital era. And yet, comments from OWS participants routinely position OWS processes as new.

One possible explanation for this view of OWS as a "new" model is the perceived importance of digital and networked media to the protest. Texts by OWS participants rarely mention digital media in direct relationship to the direct democracy championed by the movement. Only one post, in fact, noted that "Soon, the formal discussions about demands will be happening online as well as in the plaza" (Schneider, 2011b). A total of $28 \mathrm{com}$ ments in 19 different documents do make specific mention of digital media forms including blog posts, websites, mobile apps, social networking sites, online petitions, and livestreams. For the most part, these comments note the use of these digital media tools to disseminate information, raise awareness, and build solidarity. This quote from Schneider (2011a) is prototypical:

From day one, they had a (theoretically) twenty-fourhour lifestream [sic], allowing thousands of people around the world to watch what was going on in the plaza and on marches in real time. The plaza's generator-powered media center blasted out tweets, YouTube videos, blog posts and more, keeping savvy supporters informed and giving Anonymous lots of material to disseminate.

Other articles note how digital tools were used to organise resources within the encampment in Liberty Square such as library books (Sacks, 2011) or secure food (Adbusters, 2011j). One post pointed to both the potential advantages and disadvantages of social media, noting both that ability to use social media to "call out" more protestors, but also warning against allowing OWS to "fizzle out into another lefty whine and clicktivist campaign like has happened so many times in the past" (Adbusters, 2012b).

There are around a dozen posts, however, that indicate the online experiences of OWS participants influenced their understanding and organisation of the movement. Nearly half of these comments (5) compared the structure of the movement, specifically the leaderless, horizontal structure, directly to the Internet (Bleeding Cool, 2011; Elliott, 2011; Friedersdorf, 2011; Noveck, 2011; Rushkoff, 2011) with comments such as "it's a lot like the Internet-leaderless, spaceless" (Livecchia, as cited in Noveck, 2011). Protestors were not alone in this trait, however; contemporary critiques of the movement drew similar parallels. Charles C. W. Cooke (2011), for example, argues: "The Internet is not a bad comparison, actually. The Internet has a lot about it that is admirable, but it is also a completely open book which is mostly filled with mindless, narcissistic drivel, pornography, bigotry, self-delusion, paranoia, redundant nonsense, and spam".

Other OWS participants note how specific actions and services within the encampment replicated online 
experiences. Mallory Knodel (2011), for example, notes that Occuprint, an on-site t-shirt, poster, and placard printing facility, allowed materials to be "reproduced and disseminated immediately, just like on the Internet". Joanne McNeil (2011) similarly asserts that the "human mic" - the process introduced after loudspeakers were prohibited by a city ordinance in which participants in the crowd loudly echoed a speaker in order to deliver messages to those out of earshot-is "acting like a retweeta filter of redundancy". Even though the origins of the "human mic" have been traced to sources as varied as Quaker Churches and tribes in Madagascar (Ruby, as cited in Kelp-Stebbins \& Schifani, 2015, p. 5), comments such as McNeil's suggest participants understood OWS through a mediated lens in a way that minimises the historical origins of these tactics.

A number of comments link OWS directly to a digital, Internet culture and it is these comments that expressly work to separate OWS from history. Two comments in particular demonstrate this view. Ann Nocenti (as cited in Bleeding Cool, 2011) argues that OWS is "not a 'protest' movement; it is amorphous, like the Internet. It is, in some ways, a lifestyle". Here Nocenti seemingly claims that OWS was a product of that specific time, not because of the material conditions mentioned by Compton and Dyer-Witheford (2014), but because of an Internetinfluenced "lifestyle". Justin Elliott (2011) make this claim even more explicit, stating:

I have a feeling that because of the Internet and a different kind of mentality that young people have, a horizontal way of thinking about things, this movement may not just come up with some really good demands and put incredible people pressure on our politicians, but a more beautiful thing may come out of this movement: a new model of democracy, a new model of how activism can work, of how the people can have a radical democracy and have some of their demands met. This new model may well be a new kind of a horizontal thing that in some strange way works like the Internet works.

Elliott not only traces the emergence of OWS, and characteristics such as its horizontal structure, directly to the Internet, but also any possible (positive) outcomes of the movement. His comment suggests, perhaps, that activists' experiences with online tools and their commonly held attitudes and beliefs about networked media influenced the organisation of OWS. This direct linkage between media form and movement structure minimises historical antecedents and positions Occupy and other similar NSMs as unique. Thus, OWS is mediated in terms of using different digital technologies to communicate; communication is both "a means-activists use the media to communicate a message through which they achieve something-but also an end-activists use the media and in doing so they constitute flows of me- dia production, circulation, interpretation, and recirculation" (Mattoni \& Treré, 2014, p. 260). At the same time, OWS is mediatised because the meaning/understanding of OWS cannot be understood separate from the media, and it is this last context in which OWS's relationship with history becomes problematised.

\subsubsection{Privileging the Network in OWS}

The views expressed by the OWS participants in the quotations mentioned above are seemingly influenced by articles in the popular press and academia attribute the emergence of OWS's immediate forebearers, e.g., the Arab Spring, directly to services such as Facebook and Twitter. Social media in particular are described as a central component of social movements because they reinforce beliefs in the Internet as a democratising space, where everyone is free to debate issues as equals-an idea rooted in the (mistaken) association of the Web with 1960s counterculture (for a good summary, see Turner, 2006). As Fred Turner (2006, p. 1) describes: “Ubiquitous networked computing had arrived, and in its shiny array of interlinked devices, pundits, scholars and investors alike saw the image of an ideal society: decentralized, egalitarian, harmonious, and free". The decentralized structure of the Internet, coupled with the kinds of personalization, interactivity and participation possible there, fuel these utopian views (see, for example, Enzensberger, 2000). A belief in the democratising potential of networked, digital media is intrinsic to participatory culture, and references to the democratising and radical potential of digital media can be seen in references to civic protests in Iran in 2009 and demonstrations in the Middle East and North Africa in 2010 as a "Twitter Revolution" (Afshari, 2009, p. 854).

Whereas Mattoni and Treré (2014, p. 265) assert that, in the past, protestors would "adapt their political actions to the logic of mainstream media", with OWS, the myth of the egalitarian Internet became a central component of the "culture" many OWS participants claim is the source of the movement. The idea of a "digital culture" likely has its roots in Castells' (2000, p. 370) conceptualisation of the "network society", which he defines as being "made up of networks of production, power and experience, which construct a culture of virtuality in the global flows that transcend time and space". Felix Stalder (2005, p. 15) directly connects the concept of digital culture to the network society but also notes the importance of exchange and deliberation:

An open, digital, networked culture is profoundly exchange-oriented. It is much less like a book, and much more like a conversation. That is, it is built upon a two-way relationship between the fixed and the fluid enabled by new technologies. No longer all that is sold melts into the air, as Marx famously put it, but now, digital air can be turned into solids any time. 
Stadler's definition provides the foundation for the culture referred to by OWS participants-one that is, in their view, dependent upon and stems from the use of digital, networked technologies. Stalder $(2005$, p. 16) saw "fluid cultural exchanges" on digital media as "undermining a core aspect of contemporary capitalism", which mirrors one of the primary goals of OWS itself, but his focus on how the digital could be turned into "solids" also suggests his belief that this "open, digital, networked culture" is impacting offline culture as well.

Stalder $(2005$, p. 16) positions open exchange via networked technologies as central to an alternative culture "of collaborative media production, of free and open source software, of reference works such as the Wikipedia Encyclopedia, of open access scientific journals and music that is being made and remixed by the most talented of artists". Elsewhere, Stalder connects solidarity in protest movements to the ideas of collaboration, stating that a "culture of solidarity can be described as one rooted in a lived practice of sharing" (Stalder, 2013, p. 14). These are exactly the ideals that OWS tried to incorporate, at least as communicative construction, into their offline structure-the physical embodiment of a digital culture supposedly specific to networked technologies.

\section{Conclusion: Problematising Digital Cultures}

The purpose of this paper is not to debate whether a digital culture exists or not, but rather to illuminate how discourse about this culture, which stems from a mythologised version of the Internet, explicitly ignores that (media) culture and its processes have a long history and evolve over time. The above commentary from OWS protestors and scholars such as Castells privilege the role of digital, networked media. In doing so, they are, in essence, acting on media by both reflecting and further fuelling discourse that frames these media as democratising, egalitarian prerequisites for the emergence of modern protest movements such as OWS. This rhetoric in turn obfuscates the long history of social movements that also informed OWS and oversimplifies a complex set of material conditions that also ignited the movement including "an official US unemployment rate officially at $9 \%$, in reality close to $16 \%$, grotesque income polarization; evictions; bankruptcies" (see Compton \& Dyer-Witheford, 2014, p. 1203).

A kind of fetishisation of digital media persisted in academic texts published after the encampment in Liberty Square dissolved, as exemplified by Castells' (2012, p. 229) claims that Occupy was "born digital" and that the Internet "creates the conditions for a form of shared practice that allows a leaderless movement to survive, deliberate, coordinate and expand". This view, however, vastly oversimplifies what is, in reality, a complex culture and organisation borne out of and influenced by a variety of factors. Mattoni and Treré (2014, p. 256) remind us:
Social movements are neither concrete objects, such as a poster calling for a demonstration, nor palpable subjects, such as an association composed of members, and located in offices. They are, instead, ongoing and evolving processes...that interface with societies at the political, cultural, economic, and, of course, social level.

By reducing OWS to an Internet-specific phenomenon, the minutiae of the movement, its historical antecedents, and the socioeconomic developments that led to its emergence, even the fact that the occupation of Wall Street was an idea originally conceived and propagated by Adbusters, are minimised. Instead, the movement is simply understood as just being, like the Internet'. In doing so, Castells and those that make similar claims risk marginalising both the movement and the social conditions that led to its development.

\section{Conflict of Interests}

The authors declare no conflict of interests.

\section{References}

Adbusters. (2011a, September 6). Does the American left have the guts to pull this off? Adbusters. Retrieved from https://www.adbusters.org/action/occupywall street/does-the-american-left-have-the-guts-to-pullthis-off

Adbusters. (2011b, October 31). The future of \#OCCUPY. Adbusters. Retrieved from https://www.adbusters. org/action/occupywallstreet/the-future-of-occupy

Adbusters. (2011c, October 26). Hey G20, here comes \#ROBINHOOD. Adbusters. Retrieved from https://www.adbusters.org/action/occupywallstreet /hey-g20-here-comes-robinhood

Adbusters. (2011d, September 21). How you can help \#OCCUPYWALLSTREET. Adbusters. Retrieved from https://www.adbusters.org/action/occupywallstreet /how-you-can-help-occupywallstreet

Adbusters. (2011e, July 13). \#OCCUPYWALLSTREET. Adbusters. Retrieved from http://web.archive.org/web /20110720203012/http://www.adbusters.org/blogs /adbusters-blog/occupywallstreet.html

Adbusters. (2011f, September 7). \#OCCUPYWALLSTREET less than two weeks away. Adbusters. Retrieved from https://www.adbusters.org/action/occupywallstreet /occupywallstreet-less-than-two-weeks-away

Adbusters. (2011g, September 13). \#OCCUPYWALLSTREET tactical briefing. Adbusters. Retrieved from https://www.adbusters.org/action/occupywallstreet /occupywallstreet-tactical-briefing

Adbusters. (2011h, November 16). Our existential moment. Adbusters. Retrieved from https://www. adbusters.org/action/occupywallstreet/our-existenti al-moment 
Adbusters. (2011i, October 17). \#ROBINHOOD global march. Adbusters. Retrieved from https:// www.adbusters.org/action/occupywallstreet/robin hood-global-march

Adbusters. (2011j, September 19). A Tahrir moment on Wall Street. Adbusters. Retrieved from http:// www.adbusters.org/action/occupywallstreet/a-tahrir -moment-on-wall-street

Adbusters. (2012a, May 16). The globalization of laughter. Adbusters. Retrieved from https://www.adbust ers.org/action/occupywallstreet/the-globalizationof-laughter

Adbusters. (2012b, April 26). The May 2012 insurrection. Adbusters. Retrieved from https://www.ad busters.org/action/occupywallstreet/the-may-2012insurrection

Adbusters. (2012c, May 24). Occupy's spiritual quest. Adbusters. Retrieved from https://www.adbusters.org/ action/occupywallstreet/occupys-spiritual-quest

Adbusters. (2012d, April 3). \#PLAYJAZZ. Adbusters. Retrieved from https://www.adbusters.org/action/ occupywallstreet/playjazz

Adbusters. (2012e, January 25). Showdown in Chicago. Adbusters. Retrieved from https://www. adbusters.org/action/occupywallstreet/showdown-in -chicago

Afshari, R. (2009). A historic moment in Iran. Human Rights Quarterly, 31(4), 839-855.

Bennett, W. L., \& Segerberg, A. (2016). The logic of connective action: Digital media and the personalization of contentious politics. In E. Gordon \& P. Mihailidis (Eds.), Civic media: Technology, design, practice (pp. 77-106). Cambridge, MA: The MIT Press.

Bleeding Cool. (2011, November 14). Ann Nocenti on Occupy Wall Street. Bleeding Cool. Retrieved from http://www.bleedingcool.com/2011/11/14/ann-no centi-responds-to-frank-miller-on-occupy-wall-street

Burtch, A. (2011, October 23). Occupation is participation. Occupied Media. Retrieved from http://occu piedmedia.us/2011/10/occupation-is-participation

Cammaerts, B., Mattoni, A., \& McCurdy, P. (Eds.). (2013). Mediation and protest movements. Chicago, IL: University of Chicago Press.

Castañeda, E. (2012). The indignados of Spain: A precedent to occupy Wall Street. Social Movement Studies, 11(3/4), 309-319.

Castells, M. (2000). The rise of the network society. Cambridge, MA: Blackwell.

Castells, M. (2012). Networks of outrage and hope: Social movements in the internet age. Malden, MA: Polity Press.

Chelliah, J. (2012, April 4). Mother activism on the rise. Occupy. Retrieved from http://www.occupy.com/ article/mother-activism-rise

Compton, J., \& Dyer-Witheford, N. (2014). Prolegomenon to a theory of slump media. Media, Culture \& Society, 36(8), 1196-1206.

Cooke, C. C. W. (2011, October 17). Can Occupy Wall
Street make sense of itself? National Review. Retrieved from http://www.nationalreview.com/ article/280277/can-occupy-wall-street-make-senseitself-charles-c-w-cooke

Costanza-Chock, S. (2012). Mic check! Media cultures and the Occupy Movement. Social Movement Studies, 11(3/4), 375-385.

Dahlberg, L. (2001). The Internet and democratic discourse: Exploring the prospects of online deliberative forums extending the public sphere. Information, Communication \& Society, 4(4), 615-633.

Dahlberg, L. (2007). Rethinking the fragmentation of the cyberpublic: From consensus to contestation. New Media \& Society, 9(5), 827-847.

Dahlberg, L. (2011). Re-constructing digital democracy: An outline of four 'positions'. New Media \& Society, 13(6), 855-872.

Dahlgren, P. (2001). The public sphere and the net: Structure, space, and communication. In W. L. Bennett \& R. M. Entman (Eds.), Mediated politics: Communication in the future of democracy (pp. 33-55). Cambridge: Cambridge University Press.

Daubs, M. S. (2017). Integration durch Diversifikation: die Mediatisierung sozialer Bewegungen vom 'Kampf von Seattle' bis Occupy [Integration through diversification: The mediatisation of social movements from the 'Battle in Seattle' to Occupy]. In O. Jandura, M. Wendelin, M. Adolf, \& J. Wimmer (Eds.), Zwischen Integration und Diversifikation. Medien und gesellschaftlicher Zusammenhalt im digitalen Zeitalter [Between integration and diversification: Media and social cohesion in the digital age] (pp. 121-138). Wiesbaden: Springer VS.

della Porta, D. (2012). Mobilizing against the crisis, mobilizing for 'another democracy': Comparing two global waves of protest. Interface, 4(1), 274-277.

della Porta, D., \& Diani, M. (2006). Social movements: An introduction (2nd ed.). Malden, MA: Blackwell.

Eagleton-Pierce, M. (2001). The Internet and the Seattle WTO protests. Peace Review, 13(3), 331-337.

Elliott, J. (2011, October 4). The origins of Occupy Wall Street explained. Salon. Retrieved from http:// www.salon.com/2011/10/04/adbusters_occupy_wall _st

Enzensberger, H. M. (2000). Das digitale Evangelium [The digital Gospel]. Der Spiegel. Retrieved from http://www.spiegel.de/spiegel/print/d-15376 078.html

Fenton, N., \& Downey, J. (2003). Counter public spheres and global modernity. The Public, 10(1), 15-32.

Friedersdorf, C. (2011, October 17). How Occupy Wall Street is like the Internet. The Atlantic. Retrieved from http://www.theatlantic.com/technology/arch ive/2011/10/how-occupy-wall-street-is-like-the-inter net/246759

Gerbaudo, P. (2012). Tweets and the streets: Social media and contemporary activism. London: Pluto Press.

Graeber, D. (2011a, October 23). Enacting the impos- 
sible. Occupied Media. Retrieved from http://oc cupiedmedia.us/2011/10/enacting-the-impossible

Graeber, D. (2011b, September 25). Occupy Wall Street rediscovers the radical imagination. The Guardian. Retrieved from https://www.theguardian.com/com mentisfree/cifamerica/2011/sep/25/occupy-wall-str eet-protest

Gueraseva, J. (2012, March 21). Occuprint \& OWS: Notes on art as a weapon for non-violent insurrection. Groundswell. Retrieved from https://web.archive. org/web/20120515105317/http://groundswellcollec tive.com/2012/03/21/occuprint-ows-notes-on-art-as -a-weapon-for-non-violent-insurrection

Gupta, A. (2011, October 1). The revolution begins at home. Occupied Media. Retrieved from http://oc cupiedmedia.us/2011/10/the-revolution-begins-athome

Harris, P. (2011, September 21). Occupy Wall Street: The protesters speak. The Guardian. Retrieved from https://www.theguardian.com/world/blog/2011/sep /21/occupy-wall-street-protests

Hayduk, R. (2012). Global justice and OWS: Movement connections. Socialism and Democracy, 26(2), 43-50.

Hedges, C. (2011, October 14). This rebellion will not stop. Occupied Media. Retrieved from http://occu piedmedia.us/2011/10/this-rebellion-will-not-stop

Hepp, A. (2009). Researching 'mediatised worlds': Nonmediacentric media and communication research as a challenge. In N. Carpentier, I. T. Trivundža, P. Pruulmann-Vengerfeldt, E. Sundin, T. Olsson, R. Kilborn, H. Nieminen, \& B. Cammaerts (Eds.), Media and communication studies interventions and intersections (pp. 37-48). Tartu: Tartu University Press.

Jasper, J. M. (2010). Social movement theory today: Toward a theory of action? Sociology Compass, 4(11), 965-976.

Kelp-Stebbins, K., \& Schifani, A. M. (2015). The medium is the masses: Embodied amplification, urban occupation. Media Fields Journal, 9, 1-14.

Klein, N. (2011, October 14). The most important thing in the world. Occupied Media. Retrieved from http://occupiedmedia.us/2011/10/the-mostimportant-thing-in-the-world

Knodel, M. (2011, November 1). Art from the 99\%. Groundswell. Retrieved from https://web.archive. org/web/20120515105055/http://groundswellcollec tive.com/2011/11/01/art-from-the-99

Lievrouw, L. A. (2011). Alternative and activist media. Malden, MA: Polity Press.

Mattoni, A., \& Treré, E. (2014). Media practices, mediation processes, and mediatization in the study of social movements. Communication Theory, 24(3), 252-271.

McNeil, J. (2011, October 21). Occupy the Internet. The
Occupy Gazette, pp. 24-25.

Mudhai, O. F. (2006). Exploring the potential for more strategic civil society use of mobile phones. In J. Dean, J. W. Anderson, \& G. Lovink (Eds.), Reformatting politics: Information technology and global civil society (pp. 107-120). New York, NY: Routledge.

New York City General Assembly. (2011, October 14). Principles of solidarity. Occupied Media. Retrieved from http://occupiedmedia.us/2011/10/principlesof-solidarity

Noveck, J. (2011, October 8). Wall Street protesters want world to know they're just like us. Fox News. Retrieved from http://www.foxnews.com/us/2011/ 10/08/wall-street-protesters-want-world-to-knowtheyre-just-like-us.html

Occupy the SEC Working Group. (2012, April 6). The power of public comments. Occupy. Retrieved from http://www.occupy.com/article/power-publiccomments

Rheingold, H. (2002). Smart mobs: The next social revolution. Cambridge, MA: Perseus.

Rushkoff, D. (2011, October 5). Think Occupy Wall St. is a phase? You don't get it. CNN. Retrieved from http://edition.cnn.com/2011/10/05/opinion/rushk off-occupy-wall-street/index.html

Sacks, J. (2011, October 23). The people's library. Occupied Media. Retrieved from http:// occupiedmedia.us/2011/10/the-peoples-library

Scalmer, S. (2013). Mediated nonviolence as a global force: An historical perspective. In B. Cammaerts, A. Mattoni, \& P. McCurdy (Eds.), Mediation and protest movements (pp. 116-131). Chicago, IL: University of Chicago Press.

Schneider, N. (2011a, October 12). From Occupy Wall Street to Occupy everywhere. The Nation. Retrieved from https://www.thenation.com/article/occupywall-street-occupy-everywhere

Schneider, N. (2011b, October 1). Occupation for dummies. Occupied Media. Retrieved from http:// occupiedmedia.us/2011/10/occupation-for-dummies

Smith, J. (2006). Globalizing resistance: The battle of Seattle and the future of social movements. Mobilization, 6(1), 1-19.

Stalder, F. (2005). Open cultures and the nature of networks. Frankfurt am Main: Revolver-Archiv für aktuelle Kunst.

Stalder, F. (2013). Digital solidarity. Berlin: Mute Books.

Turner, F. (2006). From counterculture to cyberculture: Stewart Brand, the Whole Earth Network, and the rise of digital utopianism. Chicago, IL: University of Chicago Press.

womyn, g. (2011, October 10). NYC-Occupy together. Occupied Media. Retrieved from http:// occupiedmedia.us/2011/10/nyc-occupy-together 


\section{About the Authors}

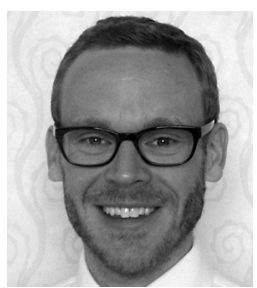

Michael S. Daubs is a Lecturer in Media Studies at Victoria University of Wellington in New Zealand. His research investigates the stories we tell both through and about media and incorporates frameworks such as mediatisation and political economy. His recent work investigates media and social movements, the commodification of Web protocols, and fake news. His co-edited volume (with Vince Manzerolle), Mobile and Ubiquitous Media: Critical and International Perspectives will be published in late 2017.

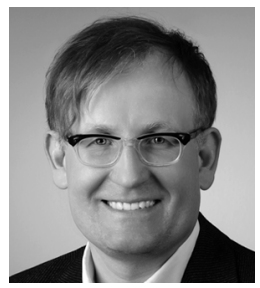

Jeffrey Wimmer is professor for communication science with emphasis on media reality at the University of Augsburg, Germany. His main research interests are sociology of media communication, digital games and virtual worlds, public and counterpublic spheres, mediatisation and participation. Jeffrey Wimmer fulfilled several empirical studies and published widely on the link between digital media, appropriation and public spheres. From 2009 to 2015 he was chairing the ECREA-section "Communication and Democracy" and the DGPuK-section "Sociology of Media Communication". 